\section{In the path of art and science: Dresden's red pill}

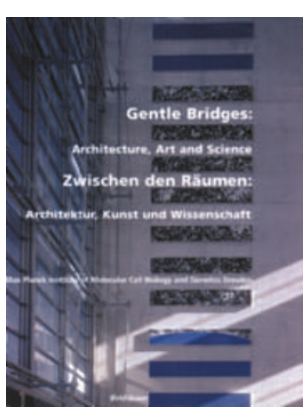

\section{Gentle Bridges: Architecture, Art and Science}

\section{by R. Anthony Hyman, Gerhard Mack, Juhani Pallasmaa and Marino Zerial}

Birkhäuser (Architectural) • 2003

Price: $\$ 49.95 / € 45.00$

When Morpheus offers a red pill and a green pill to Neo in the movie The Matrix, he offers Neo what is the equivalent of the Biblical apple for modern man: a choice between the green pill and a 'happy' and immediacy-filled life, or the red pill and a gamble that leads to enlarging one's horizons. This choice exemplifies the difficulty in breaking away from accepted currents.

I share with a growing number of people the certitude that creative art and creative science have much in common, and that it is time to dispose of the barriers that have artificially separated these fields of knowledge in recent times. It is thus a welcome surprise to find an institution-sanctioned red pill in Gentle Bridges: Architecture, Art and Science. This book presents the architectural goals and achievements of Dresden's Max Planck Institute of Molecular Cell Biology and Genetics. It attracts one's attention because of its intention and thesis that art and science have points in common, and that architecture is a natural means by which to allow such commonality to flourish.

The book, with essays in German and English, is a collage that unfortunately lacks the bridges necessary to take the reader from the first-rate science being done in the institute to the plans for the building, to a tradition of merging science and art, or to the work of a guest artist. Even though sections of the book are likely to resonate with a wide audience, the different texts seem disconnected and those on art history are not especially engaging, if only because of the sheer number of individuals mentioned per page. For example, a fluent commentary by M. Zerial on the beauty of developing systems and cellular communication explains the scientific work being done in the institute and how scientists view their work, but how this relates to the architectural project or the works of art reproduced is not so clear. Two other texts, by the architects M. Heikkinen and M. Komonen and by the artist G. Steinmann, are also interesting descriptions of the essentials of their work - the building itself and the video and photography work commissioned for the building — but here again there is no

A. Ruiz i Altaba is at the Skirball Institute, NYU School of Medicine, New York; he is also the author of Embryonic Landscapes (Actar, Barcelona, 2001) and the founding director of WetLab (www.wetlab.org), a new forum for scientific ideas in the visual arts. sense of how these relate specifically to the scientific work being done in the institute. Like the essays, the images in the book are also a mixed success. The reproductions of works of art seem strangely out of place, mostly because they seem to represent a homage to the guest artist rather than a commentary on the ideology behind the project. Although some scientific images are superb, others seem a bit generic, in part because our common bank of mental images is saturated with false-colour microphotographs; this is a major problem with many popular books that address the artistic aspects of molecular biology.

Beyond exposing the thinking behind the institute's architecture, the book draws attention to many graceful elements in the architectural design that make an apparently simple box-shaped building into an exciting venue. These include: the spiral metal staircase that recalls a double-helical structure; the photographic images that decorate the atrium; the simultaneous projection of large images of a video triptych; and the undulating forms of the entrance canopy, which breaks the rectilinear nature of the building and welcomes its guests. These motifs, reflecting the intention of the creators, make an exciting environment in which knowledge, in its many flavours, scientific and otherwise, is at the centre.

This brings us to the question of whether architecture is a pre-eminent forum where science and art meet, as possibly exemplified by Gehry's Guggenheim Museum in Bilbao or Calatrava's organic bridges. Architecture may not be a pre-eminent artistic and scientific endeavour but it can certainly accommodate aspects of both, in much the same way that scientific images can. Scientific images can be viewed as documents, but they are also inescapable works of art (full of intention and the perversion of reality). Thus, one reason for a book such as Gentle Bridges is that it celebrates the dual nature of architecture and scientific imagery, both serving a function and functioning as art.

One of the important achievements of the MPI in Dresden, exemplified in this book, is that it is this institute's purpose to house the best possible scientists together with a sense that art is omnipresent: that art and science can work together and that science has much to offer to the art community and vice versa. The choice is clear. Red is finally back in vogue.

\section{New in hardback}

\section{RNAi: A guide to Gene Silencing}

\author{
Edited By Gregory J. Hannon
}

Cold Spring Harbour Press, $£ 95 / \$ 130$

\section{Molecular Motors.}

Edited by Manfred Schliwa

John Wiley \& Sons, $£ 125 / \$ 150$ 